\title{
OPTIMALISASI PLATFORM DIGITAL DALAM PEMBELAJARAN DARING DI TENGAH PANDEMI COVID-19
}

\author{
Ferdi Arifin, Elita Ulfiana, Wihadi Admojo \\ Universitas Islam Negeri Raden Mas Said Surakarta, Jawa Tengah, Indonesia \\ Email: ferdiarf@gmail.com, elita.ulfiana@iain-surakarta.ac.id,wihadi.admojo@gmail.com
}

Received: 2020-02-15; Accepted: 2020-03-05; Published: 2020-03-15

\begin{abstract}
Abstrak
Pandemi global memaksa guru dan siswa untuk belajar dari rumah. Banyak platform dapat digunakan untuk mengganti pembelajaran offline dengan pembelajaran online. Optimalisasi platform pembelajaran digital merupakan salah satu cara untuk menyesuaikan kegiatan belajar di masa pandemi. Artikel ini bertujuan untuk menguraikan platform digital optimalisasi untuk pembelajaran online di kalangan guru di sekolah Abi Ummi. Penelitian ini menggunakan pendekatan kualitatif dan netnografi untuk memahami cara mengoptimalkan pembelajaran online di masa pandemi. Hasilnya menunjukkan bahwa media sosial dapat menjadi salah satu platform digital untuk pembelajaran online. Platfom paling digital yang digunakan oleh guru Abi Ummi adalah Google Classrom sebagai sistem manajemen pembelajaran, Youtube dan Instagram sebagai konten materi yang dibagikan, dan Whatsapp dan Telegram sebagai media messenger untuk membahas materi tersebut.
\end{abstract}

Kata Kunci: optimalisasi platform digital; pembelajaran online; sistem manajemen pembelajaran; pandemi Covid-19

\begin{abstract}
Global pandemic forces teachers and students for studying from home. Many platforms can be used for substituting offline learning to online learning. Optimalization digital learning platform is one of ways to adjust learning activities in the pandemic. This article aims to elaborate optimalization digital platform for online learning among teachers in Abi Ummi school. The research uses qualitative and netnography approach for understanding how to optimize online learning in the pandemic. The result shows that social media can be one of digital platform for online learning. The most digital platfom used by Abi Ummi teachers are Google Classrom as learning management system, Youtube and Instagram as material contents shared, and Whatsapp and Telegram as media messengers for discussing the material
\end{abstract}

Keywords : optimalization digital platform; online learning; learning management system; pandemic Covid-19

\section{PENDAHULUAN}

Sejak kuartal pertama tahun 2020 Indonesia menyatakan bahwa Covid-19 masuk di Indonesia. Hal ini kemudian membuat banyak aspek kehidupan sehari-hari berubah drastis. Rutinitas harian harus disesuaikan sedemikian rupa untuk meminimalisir penyebaran virus. Kebijakan pemerintah untuk work from home (WFH) dan school from home (SFH) menjadi salah satu bentuk adaptasi yang harus dilakukan oleh masyarakat Indonesia.

Baik murid maupun wali murid harus menjalankan rutinitasnya di rumah secara bersama-sama. Orang tua harus bisa bekerja dari rumah sembari memantu anaknya belajar secara virtual. Hal ini juga berlaku pada guru-guru yang memiliki anak yang sekolah. Mereka harus bisa menyesuaikan diri untuk mengajar siswa-siswinya sembari menemani anaknya 
sendiri belajar. Hal ini memunculkan berbagai kendala yang dialami oleh banyak orang tetapi harus diterima sehingga mereka harus bisa beradaptasi dengan keadaan.

Kendala bagi pengajar di tengah pandemi ini memang sangat kompleks ketika penerapan WFH ini berjalan cukup lama terlebih lagi mereka harus beradaptasi dengan media pembelajaran digital (Mastura \& Santaria, 2020). Dalam sebuah kasus, IBM sebagai perusahaan global sempat menerapkan karyawannya untuk WFH karena perhitungan biaya infrastruktur yang mahal. Namun demikian, selama 5 tahun penerapan WFH membuat IBM mengalami penurunan pendapatan yang drastis (Useem, 2017) "The communications technology offering the fastest, cheapest, and highest-bandwidth connection is still the office"

Dalam investigasi tersebut, Useem menjelaskan bagaimanapun juga teknologi komunikasi yang paling baik saat karyawan berada di kantor. Meskipun WFH terlihat lebih produktif, karyawan bisa bekerja melebihi jam kerja mereka sehingga membuat tekanan dalam kehidupannya. Bahkan, pembelajaran daring dinilai kurang baik untuk proses Pendidikan karakter siswa khususnya di tingkat sekolah dasar (Risalah et al., 2020) Hal ini dikarenakan guru tidak bisa memantau kondisi siswa secara langsung.

Selain itu, muncul juga masalah lain dalam proses pembelajaran daring karena kebijakan SFH dari pemerintah. Sebuah penelitian yang dilakukan pada minat belajar siswa menunjukkan bahwa muncul rasa kebosanan dari siswa yang harus menjalani proses belajar secara virtual dari rumah (Yunitasari \& Hanifah, 2020). Hal ini dipengaruhi oleh banyak faktor, seperti rendahnya literasi digital para guru sehingga model pembelajaran daring terkesan monoton; perubahan rutinitas; jaringan yang tidak stabil; alat yang kurang proper sehingga tidak optimal; dan masih banyak lagi.

Oleh karena itu, optimalisasi platform digital sebagai media pembelajaran daring harus diterapkan oleh para guru-guru. Penelitian ini mengkaji proses pembelajaran daring yang dilakukan oleh guru-guru di sekolah Abi Ummi sebagai studi kasus optimalisasi pembelajaran daring di tengah pandemi.

Pada dasarnya, ada beberapa penelitian yang sudah dilakukan terkait dengan optimalisasi pembelajaran daring. Ada sebuah upaya yang dilakukan oleh beberapa guru dalam melakukan optimalisasi pembelajaran daring di masa pandemi menggunakan buku kendali (Alimuddin, 2021) ada upaya optimalisasi pembelajaran daring yang dilakukan guruguru dengan cara memberikan referensi konten pembelajaran dari kanal-kanal yang direkomendasikan supaya bisa belajar mandiri (Sadikin, Lestari, \& Aini, 2020) ada juga optimalisasi yang dilakukan guru-guru dalam pembelajaran daring ini dengan metode blended learning yang mengupayakan tatap maya dan belajar mandiri (Purnama, 2020).

Sejauh ini sudah banyak penelitian dan pengabdian yang mengarah pada optimaliasi pembelajaran daring. Hanya saja, kebaruan dari kajian ini adalah bentuk optimalisasi model pembelajaran daring di masa pandemi memanfaatkan platform digital sehingga menjadi suatu kebaruan dalam telaah optimalisasi pembelajaran daring di masa pandemi.

\section{METODE PENELITIAN}

Jenis penelitian ini menggunakan kualitatif sebagaimana karakteristik dari metode ini menekankan pada sebuah asumsi yang berdasar pada teori-teori sosial yang sudah ada. Selain itu, metode kualitatif membantu penelitian mampu mendeskripsikan sebuah fenomena dan mendiskusikan makna yang terimplikasi di dalam fenomena tersebut (Silverman, 1985). Proses analisis tersebut menggunakan metode Netnografi, yaitu metode pengumpulan data dan analisis melalui jejaring internet (Kozinets, 2002). Beberapa tahapan 
yang dilakukan dalam metode netnografi ini adalah menentukan objek penelitian dan skala yang akan diambil. Setelah itu, pencarian data dilakukan dengan berselancar di dunia maya untuk melihat berbagai aktivitas yang dilakukan oleh objek. Setelah data terkumpul kemudian ada penginputan data dan pengkategorisasian data. Setelah data terkategorisasi kemudian dianalisis dengan pendekatan-pendekatan yang digunakan dalam penelitian (Kozinets, Dolbec, \& Earley, 2014).

Adapun data yang diambil dari penelitian ini bersumber dari guru-guru di sekolah Abi Ummi Boyololali. Selain karena sekolah ini ketat dalam menerapkan kebijakan pemerintah, para pengajar di sekolah Abi Ummi juga menggunakan platform digital tambahan selain Learning Management System sebagai upaya optimalisasi pembelajaran daring. Penelitian ini menggunakan Sembilan belas responden dari guru sebagai bentuk upaya menangkap fenomena model optimalisasi pembelajaran daring yang dilakukan.

\section{HASIL PENELITIAN DAN PEMBAHASAN}

\section{A. Mudah Dan Murah Pilihan Platform Pembelajaran Daring}

Ada banyak sekali platform atau media pembelajaran yang bisa ditemukan di internet. Beberapa di antaranya ada yang berbayar tetapi tidak sedikit juga gratis. Guruguru di sekolah Abi Ummi lebih memilih platform pembelajaran yang sekiranya dapat membantu mereka untuk melaksanakan proses pembelajaran daring secara optimal. Penggunaan platform pembelajaran digital bisa menjadi salah satu upaya untuk meningkatkan performa dalam proses pembelajaran. Pemilihan platform pembelajaran ini mampu menjadikan kegiatan belajar mengajar lebih efektif daripada menggunakan caracara lama (Mardiana \& Anggraini, 2019). Hanya saja, pemilihan platform pembelajaran tersebut harus disesuaikan dengan kebutuhan dan keadaan dari masing-masing instansi Pendidikan dan peserta ajar di masing-masing instansi tersebut.

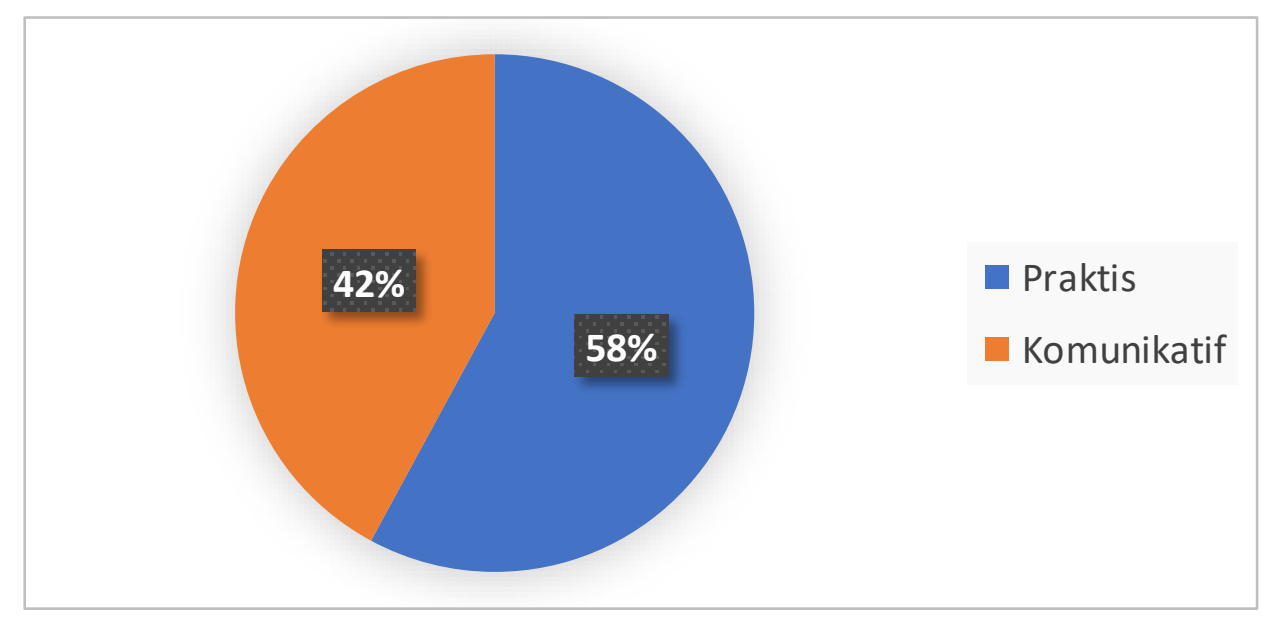

\section{Gambar 1}

\section{Presentase keputusan pemilihan platform pembelajaran berbasis digital}

Gambar 1 merepresentasikan jawaban atas pertanyaan alasan para guru memilih platform pembelajaran berbasis digital tertentu. Dari jawaban tersebut, guru-guru di sekolah Abi Ummi memiliki dua alasan utama untuk membuat keputusan platform seperti apakah yang akan digunakan, yakni alasan praktis dan komunikatif. Hal ini didasari karena pihak instansi sekolah tidak memiliki fasilitas platform pembelajaran berbasis 
digital secara mandiri sehingga para pengajar harus mencari cara sendiri untuk memilih jenis platform apa yang digunakan.

Alasan praktis yang diutarakan oleh para pengajar berdasarkan dari aksesibilitas dari semua pihak, baik guru maupun siswa. Di sisi lain, alasan komunikatif didasarkan sesuai dengan kebutuhan pembelajaran. Para guru harus bisa memilih platform yang memudahkan untuk berkomunikasi sehingga memudahkan guru dan siswa untuk diskusi terkait tema dan materi yang akan dipelajari.

Komunikasi sangat penting dalam pembelajaran secata virtual maupun blended learning (Singleton, 2013) karena komunikasi merupakan salah satu bentuk diskusi yang dapat meningkatkan aspek kritis siswa. Selain itu, komunikasi menjadi salah satu upaya seorang pengajar untuk melihat sejauh mana kemampuan dari siswa dan aspek apa saja yang perlu ditekankan dalam proses pembelajaran (Yengin, 2017).

Berdasarkan dua alasan utama tersebut, para guru di sekolah Abi Ummi hanya memiliki pilihan untuk beberapa Learning Management System (LMS) yang tersedia, seperti Google Classroom, Edomodo, Schoology, Moodle, dan SEVIMA Edlink. Kelima LMS tersebut menjadi pilihan karena memiliki fitur yang cukup untuk proses pembelajaran secara virtual. Terlebih lagi, kelima aplikasi tersebut bisa diakses secara gratis sehingga tidak membebankan para pengajar yang ingin menggunakannya. Namun demikian, kecenderungan guru hanya memilih satu LMS yang digunakan selama proses pembelajaran daring.

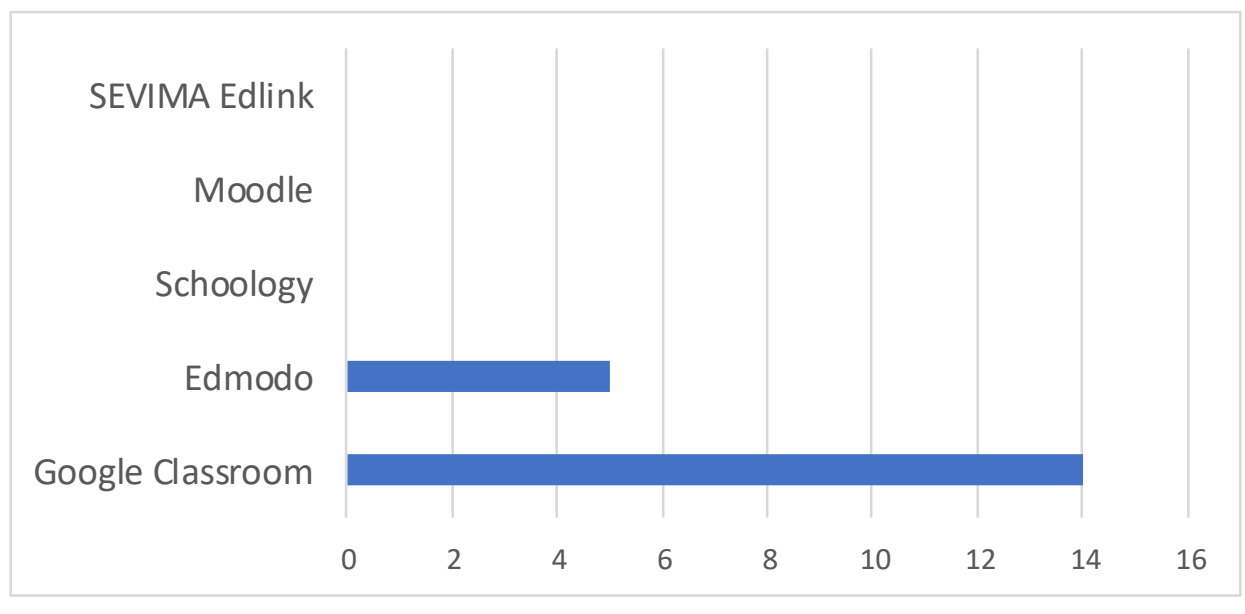

Gambar 2

Pilihan LSM guru-guru Sekolah Abi Ummi

Gambar 2 menunjukkan respon guru terhadap alasan kepraktisan sebuah LMS dan kemudahan aplikasi tersebut untuk berkomunikasi antara guru dengan siswa. Dalam kasus ini, guru-guru di sekolah Abi Ummi memilih menggunakan Google Classroom dan Edmodo sebagai LMS untuk membatu proses kegiatan belajar mengajar mereka. Selain memberikan kemudahan berkomunikasi dan kepraktisan, kedua aplikasi ini juga mudah digunakan oleh orang yang minim terhadap literasi teknologi.

Edmodo menjadi salah satu LMS pilihan karena fitur yang memudahkan pengguna layaknya bermain media sosial. Aplikasi ini juga memberikan fasilitas pembelajaran asinkron untuk lebih mengoptimalkan proses kegiatan belajar mengajar (Holland \& Muilenburg, 2011). Bahkan, ada fitur menarik dalam Edmodo, seperti Award Badge, Polling dan Parent Code selain fitur-fitur utama seperti Assignment, Gradebook, Quiz, File dan Link. 
Di samping itu, Google Classroom adalah LMS pilihan banyak guru di sekolah Abi Ummi. Hal ini karena aplikasi ini adalah salah satu produk dari perusahaan Google sehingga aplikasi ini sangat praktis untuk digunakan. Bahkan, aplikasi ini sudah diunduh sebanyak 100 juta unduhan lebih atau bisa dikatakan juga bahwa aplikasi ini memiliki pengguna lebih dari 100 juta orang.

Aplikasi ini memiliki fitur standar untuk kegiatan belajar mengajar secara virtual sehingga aplikasi ini dirasa cukup untuk menggantikan pembalajaran tatap muka di kelas. Hanya saja, sebuah penelitian studi kasus tentang efektifitas Google Classroom ini menyebutkan bahwa meskipun aplikasi ini cukup baik untuk pembelajaran virtual tetapi aplikasi ini kurang memiliki keberagam fitur untuk meningkatkan model pembelajaran serta dinilai kurang user-friendly di era perkembangan teknologi saat ini (Azhar \& lqbal, 2018). Namun demikian, para guru tidak memiliki banyak opsi untuk melihat kekurangan dan kelebihan dari masing-masing LSM yang tersedia karena pertimbangan mereka adalah free to use, mudah diakses, dan mudah untuk digunakan dalam berkomunikasi saat proses pembelajaran sedang berlangsung.

\section{B. Optimalisasi Platform Media Sosial dalam Proses Pembelajaran}

Media sosial merupakan salah satu aplikasi yang hampir pasti terinstall di semua smartphone orang-orang. Kepopuleran media sosial ditengan perkembangan internet dan teknologi informasi saat ini sangat luar biasa. Banyak aktivitas dan rutinitas yang dulunya terjadi di dunia realitas saat ini bisa terjadi di dunia maya. Bahkan, aktivitas biologis pun bisa berubah sejak adanya media sosial yang semakin berkembang ini.

Sebuah penelitian menjelaskan bahwa penggunaan media sosial di kalangan masyarakat Indonesia kian bertambah seiring berjalannya waktu. Di awal 2021, masyarakat Indonesia dalam sehari menghabiskan waktunya di Internet hingga 8 jam 52 menit; menonton televisi selama 2 jam 50 menit; melakukan aktivitas di media sosial selama 3 jam 14 menit; membaca media online selama 1 jam 38 menit; mendengarkan music selama 1 jam 30 menit; mendengarkan radio selama 33 menit; mendengarkan podcast selama 44 menit; dan menghabiskan waktu bermain game selama 1 jam 16 menit (Moreira, 2021).

Aktivitas berselancar di internet yang dilakukan oleh masyarakat Indonesia tersebut mengubah perilaku yang bersosial di dunia nyata berganti ke dunia maya. Tidak hanya Indonesia, hampir di setiap negara yang memiliki fasilitas bebas internet mengalami kejadian yang serupa. Perkembangan internet membuat perubahan perilaku yang signifikan bagi penggunanya. Namun demikian, aktivitas berselancar di internet memang cenderung dihabiskan untuk bermedia sosial daripada yang lainnya.

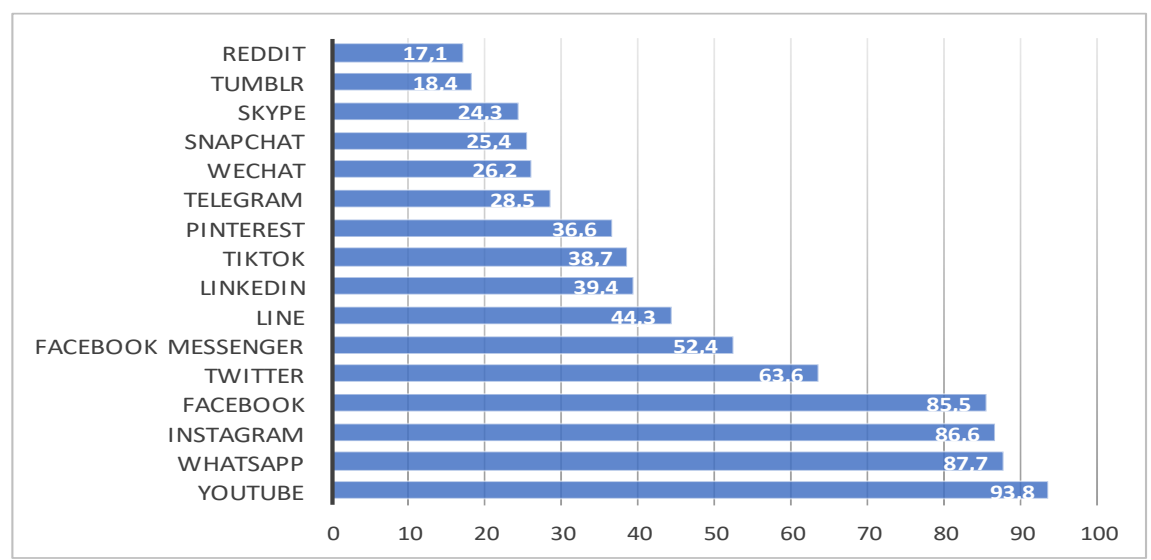

Ferdi Arifin, Elita Ulfiana, Wihadi Admojo / Optimalisasi Platform Digital Dalam Pembelajaran Daring Di Tengah Pandemi Covid-19 


\section{Gambar 3 \\ Presentase penggunaan media sosial di Indonesia}

Gambar 3 menunjukkan sejumlah presentase media sosial yang sering digunakan oleh masyarakat Indonesia (Moreira, 2021). Data tersebut merupakan gabungan dari media sosial dan media messenger. Adapun media sosial yang populer di kalangan masyarakat Indonesia berarti yang tertinggi adalah Youtube 93,8\%, Instagram $86,6 \%$, Facebook 85,5\%, Twitter 63,6\%, LinkedIn 39,4\%, TikTok 38,7\%, Pinterest 36,6\%, Tumblr $18,4 \%$, dan Reddit 17,1\%. Di sisi lain, media messenger yang populer digunakan adalah Whatsapp 87,7\%, Facebook Messenger 52,4\%, Line 44,3\%, Telegram 28,5\%, Wechat $26,2 \%$, Snapchat $25,4 \%$, dan Skype $24,3 \%$.

Data tersebut merupakan sebuah fakta bahwa penggunaan internet untuk media pembelajaran masih sangat rendah. Menurut GlobalWeblndex (GWI) menyatakan bahwa generasi Z (16-23 tahun) lebih cenderung membuka aplikasi Instagram daripada yang lainnya (Pusparisa, 2021) Oleh karena itu, pelajar di Indonesia cenderung memiliki minat kepada media sosial Instagram daripada media yang lainnya.

Hal ini menjadi salah satu upaya yang bisa diambil untuk meningkatkan model pembelajaran daring yang saat ini sedang terjadi di tengah pandemi. Kejenuhan dalam penyampaian materi pembelajaran secara virtual mampu membuat siswa kurang konsentrasi dan motivasi. Perlu adanya optimalisasi model pembelajaran daring dengan mengoptimalkan media sosial yang banyak diminati oleh siswa.

Besarnya potensi media sosial sebagai sebuah platform yang banyak diakses oleh generasi $Z$ atau generasi pelajar di tahun ini menjadikan itu sebagai sebuah celah untuk pengoptimalan media pembelajaran secara daring. Oleh karena itu, penelitian ini melihat apakah guru-guru sekolah Abi Ummi juga aktif menggunakan media sosial melalui pertanyaan jenis media sosial yang aktif mereka gunakan.

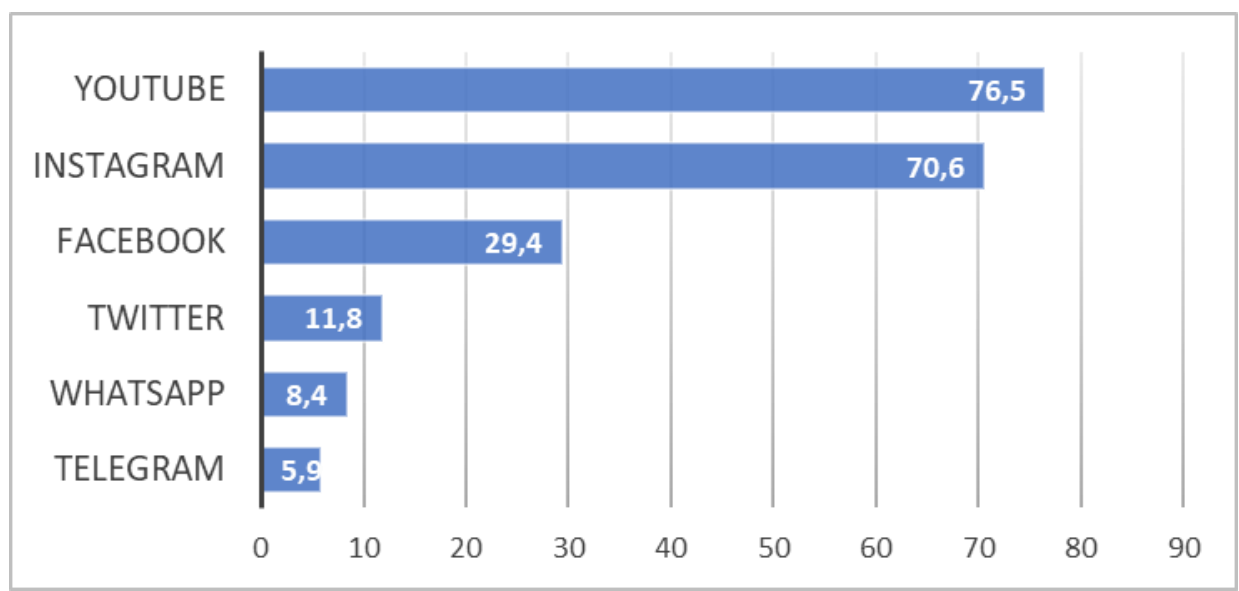

Gambar 4

Presentase media sosial yang digunakan guru-guru sekolah Abi Ummi

Pada gambar 4 menunjukkan Youtube menjadi media sosial favorit bagi guru-guru sekolah Abi Ummi. Presentase guru active menggunakan Youtube 76,5\%, Instagram 70,6\%, Facebook 29,4\%, Twitter 11,8\%, Whatsapp 8,4\%, dan Telegram 5,9\%. Berdasarkan data tersebut, guru yang aktif menggunakan Instagram terbilang cukup banyak di bawah Youtube. 
Namun demikian, penelitian ini juga menanyakan media sosial apakah yang digunakan sebagai sarana pendukung untuk pembelajaran daring selama pandemi ini. Pertanyaan seperti ini kami ajukan untuk memvalidasi apakah minat guru-guru dalam penggunaan media sosial sesuai dengan media sosial yang digunakan untuk pendukung pembelajaran di kelas.

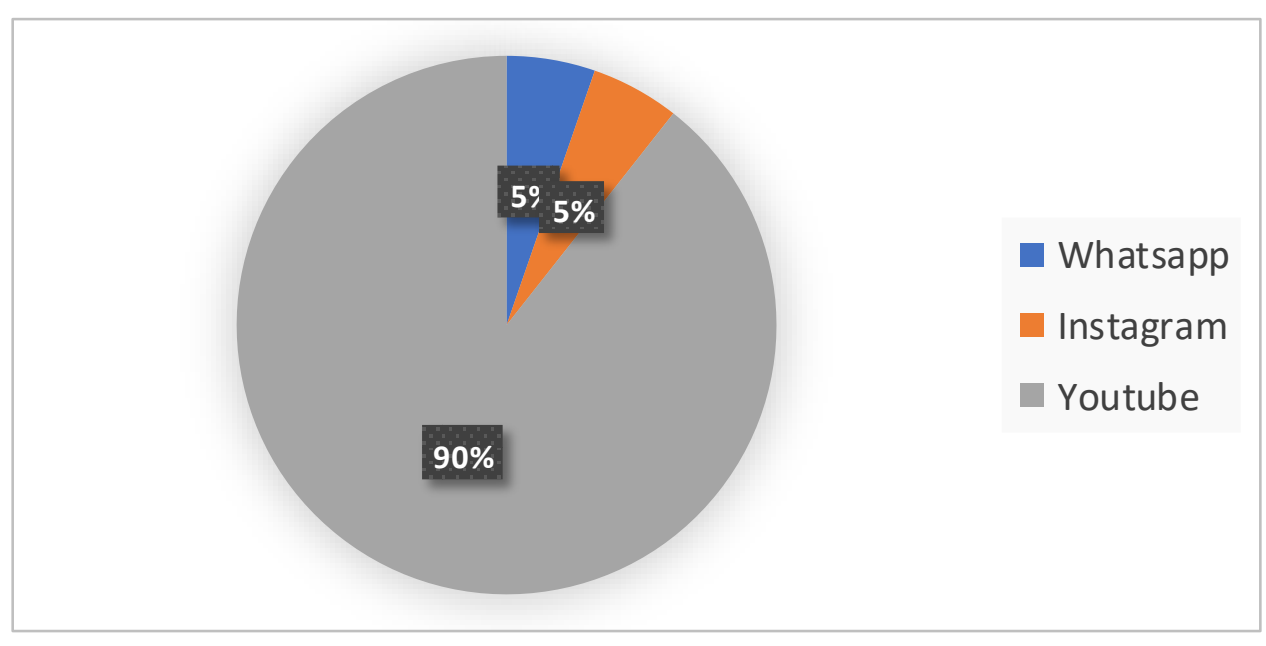

\section{Gambar 5 \\ Presentase penggunaan media sosial sebagai sarana pendukung pembelajaran}

Pada gambar 5 menunjukkan bahwa para guru di sekolah Abi Ummi lebih cenderung memanfaatkan Youtube sebagai media bantu untuk pembelajaran daring. Jumlah mereka yang memanfaatkan Youtube sebagai alat bantu pembelajaran daring sebanyak $90 \%$, Instagram 5\% dan Whatsapp 5\%. Hal ini ternyata bertentangan dengan gambar 4 yang menggambarkan media sosial yang aktif mereka gunakan.

Selain itu, pendapat GWI yang menyatakan bahwa generasi $Z$ atau pelajar saat ini lebih aktif menggunakan Instagram daripada media sosial lain tampaknya tidak dijadikan rujukan oleh para guru. Hal ini dikarenakan alasan dasar para guru yang menganggap kepraktisan dan komunikasi menjadi dasar pemilihan media sosial yang digunakan.

Beberapa alasan pemilihan Youtube sebagai media sosial alat bantu pembelajaran daring dijelaskan dalam aspek berikut :

1. Aksesabilitas. Kemudahan akses media sosial Youtube menjadi salah satu alasan kuat kenapa para guru memilih Youtube sebagai alat bantu utama dalam pembelajaran daring.

2. Kualitas. Media sosial Youtube memberikan kualitas yang mumpuni, baik kualitas konten video yang dapat High Definition (HD) sehingga video yang dibuat bisa sangat jelas.

3. Familiar. Youtube menjadi salah satu media sosial yang populer sehingga siswa sudah familiar jika diminta untuk mengakses materi yang bersumber dari Youtube.

4. Ramah Teknologi. Ada beberapa guru yang beranggapan membuat video dan membagikannya kepada siswa dapat mengganggu ruang penyimpanan. Youtube menjadi jawaban untuk mengurangi kuota penyimpanan memori.

5. Kaya referensi. Ada banyak konten atau materi pembelajaran yang diunggah dalam Youtube. Satu materi pembelajaran bisa diunggah oleh beberapa akun Youtube sehingga para guru bisa memilih konten seperti apa yang akan dibagikan kepada siswa.

Ferdi Arifin, Elita Ulfiana, Wihadi Admojo / Optimalisasi Platform Digital Dalam Pembelajaran Daring Di Tengah Pandemi Covid-19 
Penggunaan Youtube sebagai salah satu media sosial alat bantu pembelajaran tidak serta merta dilepaskan begitu saja oleh para guru. Kebanyakan guru memberikan referensi konten video dari Youtube sesuai dengan materi yang sedang berlangsung. Para guru kemudian melakukan evaluasi untuk memastikan apakah materi yang dipelajari sendiri dari Youtube sudah dipahami.

Para guru melakukan evaluasi menggunakan beberapa metode yang digunakan, seperti mendiskusikan konten video dari Youtube melalui pesan di group Whatsapp atau di Instagram; mengadakan quis sederhana untuk memastikan hasil belajar siswa dari Youtube; dan meminta siswa untuk melakukan review dari hasil belajar mandiri melalui konten Youtube yang diberikan guru.

Dengan kata lain, para guru menggunakan beberapa metode pembelajaran daring melalui beberapa platform digital yang dinilai mampu untuk menggatikan proses pembelajaran tatap muka secara langsung. Para guru menggunakan LMS sebagai platform dasar untuk mengadakan kelas, media sosial Youtube maupun Instagram digunakan untuk memberikan materi secara virtual dalam bentuk video yang kemudian ditautkan ke dalam LMS, kemudian media messenger (Whatsapp atau Telegram) digunakan untuk berdiskusi secara realtime kepada siswa.

Namun demikian, pembelajaran secara daring masih dirasa berat dilakukan. Masih ada kendala-kendala yang sulit untuk diperbaiki. Hal yang menjadi permasalahan utama dalam proses pembelajaran dari adalah jaringan. Persoalan jaringan menjadi masalah bagi semuanya, baik guru maupun siswanya. Kendala jaringan terjadi karena jaringan internet belum merata di seluruh wilayah Indonesia. Masih ada beberapa wilayah dengan jaringan yang kurang baik sehingga sering terputus jaringannya saat proses pembelajaran daring dilakukan.

\section{KESIMPULAN}

Pembelajaran daring saat ini memang harus dilakukan di tengan pandemi Covid-19 yang belum kunjung usai. Kebijakan pemerintah untuk menjauhi kerumunan menjadikan rutinitas belajar mengajar di sekolah harus dibatasi demi keselamatan bersama. Banyaknya fasilitas dari berbagai platform digital untuk pembelajaran daring menjadi jalan tengah untuk menggantikan pertemuan tatap muka secara langsung menjadi pertemuan tatap muka secara virtual.

Guru-guru di sekolah Abi Ummi memanfaatkan LMS yang gratis, praktis, dan komunikatif sebagai sarana pengganti pertemuan kelas secara langsung. Google Classroom dan Edmodo menjadi LMS pilihan bagi mereka karena memiliki fitur-fitur yang dibutuhkan. Selain itu, pemanfaatan media sosial juga digunakan untuk mengoptimalkan pembelajaran daring, seperti penggunaan Youtube, Instagram, Whatsapp, dan lain sebagainya.

Ada banyak cara pembelajaran daring yang bisa digunakan untuk menyesuaikan diri dengan pandemi, tetapi ada saja masalah atau kendala yang muncul, seperti kendala jaringan yang tidak stabil. Kesimpulan penting dalam penelitian ini bahwa pembelajaran daring harus disesuaikan dengan situasi dan kondisi dari pengajar dan pemelajar sehingga terciptanya kultur belajar yang paling mendekati ideal di tengah pandemi ini 


\section{DAFTAR PUSTAKA}

Alimuddin, Johar. (2021). Optimalisasi Pembelajaran Daring Pada Masa Pandemi Covid-19 Di Mi Al Mahdy Sindangsari Majenang. Elementary School: Jurnal Pendidikan Dan Pembelajaran Ke-Sd-An, 8(2), 374-379.

Azhar, Kaukab Abid, \& Iqbal, Nayab. (2018). Effectiveness Of Google Classroom: Teachers' Perceptions. Prizren Social Science Journal, 2(2), 52-66.

Holland, Catherine, \& Muilenburg, Lin. (2011). Supporting Student Collaboration: Edmodo In The Classroom. Society For Information Technology \& Teacher Education International Conference, 3232-3236. Association For The Advancement Of Computing In Education (Aace).

Kozinets, Robert V. (2002). The Field Behind The Screen: Using Netnography For Marketing Research In Online Communities. Journal Of Marketing Research, 39(1), 61-72.

Kozinets, Robert V, Dolbec, Pierre Yann, \& Earley, Amanda. (2014). Netnographic Analysis: Understanding Culture Through Social Media Data. The Sage Handbook Of Qualitative Data Analysis, 262-276.

Mardiana, Dina, \& Anggraini, Daniar Chandra. (2019). The Effectiveness Of Utilising WebLearning Media Towards Islamic Education Learning (Pai) Outcome In The Era Of Industrial Revolution 4.0. International Journal Of Innovation, Creativity And Change, 8(1), 80-96.

Mastura, Mastura, \& Santaria, Rustan. (2020). Dampak Pandemi Covid-19 Terhadap Proses Pengajaran Bagi Guru Dan Siswa. Jurnal Studi Guru Dan Pembelajaran, 3(2), 289295.

Moreira, Wanessa De Andrade. (2021). Smart Speakers And The News In Portuguese: Consumption Pattern And Challenges For Content Producers.

Purnama, Medina Nur Asyifah. (2020). Blended Learning Sebagai Sarana Optimalisasi Pembelajaran Daring Di Era New Normal. Scaffolding: Jurnal Pendidikan Islam Dan Multikulturalisme, 2(02), 106-121.

Risalah, Ainur, Ibad, W., Maghfiroh, L., Azza, M. I., Cahyani, S. A., \& Ulfayati, Z. A. (2020). Dampak Pandemi Covid-19 Terhadap Kegiatan Belajar Mengajar Di Mi/Sd (Studi Kbm Berbasis Daring Bagi Guru Dan Siswa). Jiees: Journal Of Islamic Education At Elementary School, 1(1), 10-16.

Sadikin, Irma Savitri, Lestari, Sri, \& Aini, Safi. (2020). Pembelajaran Daring Interaktif, Bermakna Dan Menarik Sebagai Upaya Optimalisasi Proses Pembelajaran Masa Pandemi Covid-19. Jurnal Pengabdian Pada Masyarakat, 5(4), 897-905.

Silverman, David. (1985). Qualitative Methodology And Sociology: Describing The Social World. Gower Publishing Company.

Singleton, Devena M. (2013). Transitioning To Blended Learning: The Importance Of Communication And Culture. Journal Of Applied Learning Technology, 3(1).

Useem, Jerry. (2017). When Working From Home Doesn’t Work. The Atlantic, 3.

Ferdi Arifin, Elita Ulfiana, Wihadi Admojo / Optimalisasi Platform Digital Dalam Pembelajaran Daring Di Tengah Pandemi Covid-19 
Yengin, Ilker. (2017). Importance Of Feedback In Teaching, Communication And Information Systems For Learning. Komunikacija I Kultura Online, 1(1), 309-317.

Yunitasari, Ria, \& Hanifah, Umi. (2020). Edukatif: Jurnal IImu Pendidikan.

(C) 2020 by the authors. Submitted for possible open access publication under the terms and conditions of the Creative Commons Attribution (CC BY SA) license (https://creativecommons.org/licenses/by-sa/4.0/) 